\title{
EXTRATO DO RELATORIO DO BIBLIOTECÁRIO DA FACULDADE DE DIREITO
}

Cumprindo as disposições do Estatuto dos Funcionarios Publicos do Estado de São Paulo, artigo 222, XVI, tenho a honra de apresentar a V. Excia. o relatorio do movimento da BIBLIOTECA DA FACULDADE DE DIREITO, no ano findo de 1946, bem como dos serviços executados sob a orientação desta Chefia Técnica.

Frequência e consultas - Registaram-se 15.909 consultas tendo sido 13.250 de estudantes e 2.659 ide estranhos, conforme discrimina o mapa em anexo.

Funcionamento da consulta - o funcionamento da consulta prosseguiu no horario antigo, isto é, das 8 às 12 horas e das 14 às 18 horas. As 2 horas de interrupção correspondem ao periodo de almogo.

Catalogos - Continuaram os trabalhos de catalogação, com a refichagem de livros existentes e com a classificação e fichagem dos novos violumes entrados.

Obras entradas - Entraram 1.515 obras das quais, 749 por compra, 555 por doação e 211 por permuta.

Encadernações - Foram executadas na oficina anexa ̀̀ Bibliotecá 295 encadernações. Foram feitas, fora, mediante concorrência, 1.856 volumes de obras e revistas e 112 volumes de jornais.

Seção biblioiátrica - Continua, regularmente, a desinfecção e a conservação dos volumes existentes.

Revista da Faculdade de Direito - Imprimiu-se em 19461 voIume da Revista da Faculdade correspondente ao tomo 40 (extraordinario) de 1945, em homenagem ao professor Braz de Souza Arruda. Distribuiu-se a publicação sob o criterio adotado, suspensa a remessa para os paises europeus.

Publicações da Faculdade - Esteve a meu cargo a organização e impressão do Anuario e programas do curso de bacharelado, serviço executado pelas Oficinas Graficas da "Revista dos Tribunais", desta capital. Os 1.000 (mil) exemplares recebidos foram entregues à Secretaria da Faculdade. 
Assinaturas de jornais e revistas - Para o ano referido tomaram-se as seguintes assinaturas, mediante autorização da Diretoria da Faculdade e de acordo com a concorrência feita: "Jornal do Comercio" - Rio de Janeiro; "Diario Oficial da União" - $1^{\mathrm{a}}$., $3^{\mathrm{a}}$. e $4^{\mathrm{a}}$. seç̧ões — Rio de Janeiro; "Diario da Justiça" — Rio de Janeiro; "Revista de Direito Civil, Comercial e Criminal de Bento de Faria - Rio de Janeiro; "Revista Fiscal e de Legislação da Fazenda" - Rio de Janeiro; "Mensário do "Jornal do Comercio" - Rio de Janeiro; "Direito", de Clovis Bevilaqua e Eduardo Es. pinola - Rio de Janeiro. 